\title{
Pengaruh Profitabilitas, Ukuran Perusahaan dan Struktur Modal terhadap peringkat Obligasi pada Perusahaan Sektor Keuangan yang \\ Terdaftar di Bursa Efek Indonesia Periode 2013 - 2016
}

\author{
Noviarti $i^{1 *}$ \\ * Dosen Tetap Program S1 Jurusan Manajemen Fakultas Ekonomi Universitas Satya Negara Indonesia \\ noviarti.arif@gmail.com
}

\begin{abstract}
The purpose of the study was to examine the effect of profitability, firm size and capital structure on bond rating. Sampling technique with purposive sampling. Number of samples from 8 financial sector companies with observation period over 4 years. The analysis technique used is ordinal logistic regression. The test results show that the profitability and size of the company have a negative and significant impact on the rating of bonds. And the capital structure has a negative and significant effect on the bond rating. And simultaneously profitability, firm size and capital structure affect the rating of bonds. Keywords: Bond Rating, Profitability, Firm Size and Capital Structure
\end{abstract}

\section{PENDAHULUAN}

Obligasi yaitu surat utang yang dikeluarkan sebuah badan hukum dengan jangka waktu minimum lima tahun. Dalam surat utang tersebut ditentukan pembayaran bunga (kupon) dan periode pembayaran kuponnya, serta tanggal jatuh temponya.

Ada beberapa risiko yang harus dihadapi bila kita telah melakukan investasi pada obligasi. Risiko paling besar yang akan kita hadapi yaitu kemungkinan tidak dibayarnya pokok (principal) dari obligasi dan bunganya. Hal ini akan terjadi bila perusahaan yang mengeluarkan obligasi tersebut mengalami masalah keuangan yang tidak diungkapkan kepada publik. Perubahan tingkat bunga juga merupakan salah satu faktor risiko yang dihadapi oleh investor pemegang obigasi. Aspek lain yang perlu diperhatikan investor yaitu peringkat dari obligasi tersebut karena merupakan patokan kita untuk melakukan investasi. Perusahaan yang melakukan peringkat untuk obligasi dan surat utang lainnya yaitu Pefindo atau Kasnic Indonesia.

Pasar obligasi Indonesia mencatatkan pertumbuhan tercepat kedua di kawasan Asia Timur setelah Vietnam. Pada akhir kuartal IV 2013, pasar obligasi Indonesia tumbuh 6,8 persen dan 20,1 persen dibandingkan tahun lalu menjadi 108 miliar dolar AS. Obligasi pemerintah tumbuh 7,9 persen pada kuartal tersebut dan tumbuh 20,9 persen dibandingkan tahun lalu, menjadi 90 miliar dolar AS. Obligasi korporasi tumbuh 1,5 persen dalam kuartal ini dan 16,4 persen dibandingkan tahun lalu menjadi 18 miliar dolar AS.

Fenomena yang terjadi pada perusahaan PT . Bank Nasional Indonesia Tbk. Dengan menggunakan indikator ROA, pada tahun 2014 ROA mengalami penurunan dari 2.60 turun menjadi 1.80 sedangkan peringkat obligasi tidak mengalami penurunan. Ukuran perusahaan (SIZE) pada Bank Tabungan Negara Tbk. dengan indikator total Aset dalam Rupiah Mengalami kenaikan setiap tahunnya namun peringkat obligasi tidak mengalami kenaikan. Pada struktur modal dengan indikator DER pada PT. Bank Mayapada Tbk mengalami penurunan pada tahun 2014 sebesar 11,68 sampai tahun 2014 namun demikian peringkat obligasi tidak mengalami kenaikan 
Beberapa peneliti terdahulu telah melakukan penelitian tentang variabel ROA, SIZE dan DER tetapi masih terdapat Research Gap. Hasil penelitian yang dilakukan oleh Malhotra (2010), menunjukan bahwa ROA berpengaruh terhadap peringkat obligasi. Hasil tersebut tidak sesuai dengan Tetty Widiyastuti (2014), Alatas Zaenab (2014) menunjukan bahwa ROA tidak berpengaruh terhadap peringkat obligasi. Penelitian yang dilakukan oleh Ni Made Sri (2016) menunjukan bahwa SIZE berpengaruh terhadap peringkat obligasi, hasil tersebut tidak sesuai dengan Hadianto (2010), Teguh Parmono (2016) menunjukan bahwa SIZE tidak berpengaruh terhadap peringkat obligasi. Kemudian penelitian yang dilakukan Eka Wahyu (2012), menunjukan bahwa (DER) berpengaruh terhadap peringkat obligasi, hasil tersebut tidak sesuai dengan Siti Hariyat (2012), Ni Made Sri (2016) menunjukan bahwa (DER) tidak berpengaruh terhadap peringkat obligasi.

Berdasarkan fenomena dan masih terdapat gap dari hasil penelitian terdahulu, maka penelitian berikutnya masih dibutuhukan, dengan ini penulis tertarik ingin meneliti dengan menggunakan judul, "Pengaruh Profitabilitas, Ukuran Perusahaan Dan Struktur Modal Terhadap Peringkat Obligasi Pada Perusahaan Sektor Keuangan". KERANGKA PEMIKIRAN TEORITIS

Obligasi atau Bond adalah suatu kontrak jangka panjang, dimana peminjam dana setuju untuk membayar bunga dan pokok pinjaman, pada tanggal tertentu, kepada pemegang obligasi menurut Ahmad dan Herni (49: 2014). Sedangkan menurut Bursa Efek Indonesia (2014) mendefinisikan obligasi merupakan surat hutang jangka menengah/panjang yang dapat dipindah tangankan yang berisi janji dari pihak yang menerbitkan untuk membayar imbalan berupa bunga pada periode tertentu dan melunasi pokok hutang pada waktu yang telah ditentukan kepada pihak pembeli obligasi tersebut.

\section{Jenis-Jenis Obligasi}

Jenis Obligasi bedasarkan penerbitnya menurut (BEI, 2010) antara lain :

1. Corporate Bonds Obligasi yang diterbitkan oleh perusahaan, baik yang berbentuk Badan Usaha Milik Negera (BUMN) atau badan usaha swasta.

2. Government Bonds Obligasi yang diterbitkan oleh pemerintahan pusat.

3. Municipal Bonds Obligasi yang diterbitkan oleh pemerintahan daerah untuk membiayai proyek-proyek yang berkaitan dengan kepentingan publik (public utility).

\section{Peringkat Obligasi (Bond Rating)}

Peringkat obligasi perusahaan memberikan petunjuk bagi investor tentang kualitas investasi obligasi yang mereka minati. Peringkat obligasi (bond rating) adalah simbol-simbol karakter yang diberikan oleh agen peringkat untuk menunjukkan risiko dari obligasi. Dua buah agen peringkat obligasi terkenal di dunia adalah Standard \& Poor's (S\&P) Corporation dan Moody's Investor Service Inc. Di Indonesia obligasi diperingkat oleh PT PEFINDO yang didirikan tanggal 21 Desember 1993 dan PT KASNIC Creding Rating.

Peringkat obligasi merupakan skala risiko dari semua obligasi yang diperdagangkan. Skala ini menunjukkan seberapa aman suatu obligasi bagi investor. Keamanan ini ditunjukkan dari kemampuan perusahaan dalam membayar bunga dan pelunasan pokok pinjaman (Linandarini, 2010)..

\section{Lembaga Pemeringkat Obligasi}

Lembaga pemeringkat obligasi adalah lembaga independen yang menerbitkan peringkat hutang bagi para emiten. Jewell dan livingston (dalam Setyawati 2011) menyatakan bahwa para investor menghadapi masalah informasi yang disebabkan beragamnya karakteristik dari penerbit obligasi.

Terdapat beberapa lembaga pemeringkat yang di akui oleh Bank Indonesia (BI) yang tercantum dalam lampiran surat edaran Bank Indonesia Nomor 7/8/DPNP Tanggal 31 Maret 
2005, antara lain Standard And Poor's Rating, Moody's Indonesia, Fitch Rating, Kasnic Kredit Rating Indonesia, dan Pemeringkat Efek Indonesia (PEFINDO). (Lampiran Surat Edaran Bank Indonesia Nomor 7/8/DPNP, 2005). Obligasi yang dijual kepublik dalam prespektif pembeli melihatnya berdasarkan peringkat (rating).

Di Indonesia terdapat dua lembaga pemeringkat sekuritas hutang, yaitu PT. PEFINDO (Pemeringkat Efek Indonesia) dan Moody" $\mathrm{s}$ Indonesia. PT. PEFINDO atau "PT Pemeringkat Efek Indonesia" didirikan di Jakarta pada tanggal 21 Desember 1993, melalui inisiatif dari BAPEPAM (Badan Pengawas Pasar Modal) yang sekarang bergati nama menjadi OJK (Otoritas Jasa Keuangan), dan Bank Indonesia (Bank Sentral). Pada tanggal 13 Agustus 1994, PT. PEFINDO memperoleh izin usaha (No. 39/PM-PI/1994) dari BAPEPAM dan salah satu lembaga penunjang Pasar Modal Indonesia.

\section{Tabel 1}

Peringkat Obligasi berdasarkan PT. PEFINDO

\begin{tabular}{|c|c|c|}
\hline Simbol & Kategori & Arti \\
\hline idAAA & Investment Grade & $\begin{array}{l}\text { Merupakan peringkat tertinggi yang menggambarkan obligor } \\
\text { memiliki kapasitas yang superior untuk memenuhi komitmen } \\
\text { financial jangka panjang dalam pembayaran hutangnya. }\end{array}$ \\
\hline idAA & Investment Grade & $\begin{array}{l}\text { Merupakan peringkat yang menggambarkan obligor memiliki } \\
\text { kapasitas yang sangat kuat untuk memenuhi komitmen } \\
\text { finansial jangka panjang dalam pembayaran hutangnya } \\
\text { relative terhadap obligor. }\end{array}$ \\
\hline idA & Investment Grade & $\begin{array}{l}\text { Merupakan peringkat yang menggambarkan obligor memiliki } \\
\text { kapasitas yang kuat untuk memenuhi komitmen finansial } \\
\text { jangka panjang dalam pembayaran hutangnya relative } \\
\text { terhdapa obligor Indonesia lainnya. Bagaimanapun sekuritas } \\
\text { hutang ini lebih mudah terpengaruh terhadap perubahan } \\
\text { kondisi ekonomi dibandingkan sekuritas hutang dengan } \\
\text { rating yang lebih tinggi. }\end{array}$ \\
\hline idBBB & Investment Grade & $\begin{array}{l}\text { Merupakan peringkat yang menggambarkan obligor memiliki } \\
\text { kapasitas yang cukup untuk memenuhi komitmen finansial } \\
\text { jangka panjang dalam pembayaran hutangnya relative } \\
\text { terhadap obligor Indonesia lainnya. bagaimanapun perubahan } \\
\text { kondisi ekonomi dianggap dapat melemahkan kapasitas } \\
\text { obligor dalam memenuhi komitmen fianansial jangka } \\
\text { panjang dalam pembayaran hutangnya. }\end{array}$ \\
\hline $\mathrm{idBB}$ & $\begin{array}{l}\text { Non Investment } \\
\text { Grade }\end{array}$ & $\begin{array}{l}\text { Merupakan peringkat yang menggambarkan obligor memiliki } \\
\text { kapasitas yang agak lemah untuk memenuhi komitmen } \\
\text { finansial jangka panjang dalam pembayaran hutangnya } \\
\text { relative terhadap obligor Indonesia lainnya. kapasitas obligor } \\
\text { untuk memenuhi komitmen finansial jangka panjang dalam } \\
\text { pembayaran hutangnya mudah terpengaruh oleh } \\
\text { ketidakpastian, atau perubahan kondisi bisnis, keuangan dan } \\
\text { kondisi ekonomi lainnya. }\end{array}$ \\
\hline $\mathrm{idB}$ & $\begin{array}{l}\text { Non Investment } \\
\text { Grade }\end{array}$ & $\begin{array}{l}\text { Merupakan peringkat yang menggambarkan obligor memiliki } \\
\text { kapasitas yang lemah untuk memnuhi komitmen finansial } \\
\text { jangka panjang dalam pembayaran hutangnya relative } \\
\text { terhadap obligor Indonesia lainnya. walaupun obligor kini } \\
\text { memiliki kapasitas untuk memenuhi komitmen finansial } \\
\text { jangka panjang dalam pembayaran hutangnya, adanya } \\
\text { perubahan kondisi-kondisi bisnis, keuangan dan kondisi }\end{array}$ \\
\hline
\end{tabular}




\begin{tabular}{|l|l|l|}
\hline & & $\begin{array}{l}\text { ekonomi lainnya dapat melemahkan kapasitas atau } \\
\text { willingness pemenuhan kewajiban obligor. }\end{array}$ \\
\hline idCCC & $\begin{array}{l}\text { Non Investment } \\
\text { Grade }\end{array}$ & $\begin{array}{l}\text { Merupakan peringkat yang menggambarkan obligor memiliki } \\
\text { kapasitas yang rentan untuk tidak memenuhi komitmen } \\
\text { finansial jangka panjang dalam pembayaran hutangnya } \\
\text { relative terhadap obligor Indonesia lainnya. }\end{array}$ \\
\hline idD & $\begin{array}{l}\text { Non Investment } \\
\text { Grade }\end{array}$ & $\begin{array}{l}\text { Merupakan peringkat yang menggambarkan obligor tidak } \\
\text { memiliki kapasitas untuk memenuhi komitmen finansial } \\
\text { jangka panjang dlaam pembayaran hutangnya relative } \\
\text { terhadap obligor Indonesia lainnya. Dengan kata lain obligor } \\
\text { dalam kondisi default. }\end{array}$ \\
\hline
\end{tabular}

Sumber : PT. PEFINDO

\section{Faktor-faktor yang Mempengaruhi Peringkat Obligasi}

Altman (2000) menyatakan bahwa para agen pemeringkat menggunakan berbagai faktor untuk menilai dan memberikan peringkat kepada obligasi perusahaan. Salah satu faktor yang digunakan oleh agen pemeringkat adalah informasi akuntansi yang tersedia. Informasi ini diberikan dalam bentuk laporan keuangan perusahaan. Bagian dari laporan keuangan yang mendapatkan perhatian paling besar untuk digunakan dalam memprediksi peringkat obligasi adalah profitabilitas, likuiditas, size perusahaan, dan growth perusahaan.

Ukuran perusahaan (size) Ukuran perusahaan merupakan pengukur yang menunjukkan besar kecilnya perusahaan. Ukuran perusahaan dapat diukur dengan menggunakan total aset, penjualan, dan ekuitas (Andry, 2005). Menurut Devi (2007) menyatakan bahwa perusahaan kecil memiliki risiko yang lebih besar dibanding dengan perusahaan besar. Aset yang dimiliki perusahaan besar relatif lebih besar jumlahnya sehingga dengan aset tersebut dapat digunakan untuk jaminan membayar obligasi. Andry (2005) menyatakan bahwa total utang dan ukuran perusahaan memiliki korelasi kuat dan positif. Dengan kata lain firm size dapat digunakan sebagai pengukur total utang (termasuk obligasi), sehingga secara tidak langsung ukuran perusahaan berpengaruh pada peringkat obligasi.

\section{Definisi Profitabiltas}

Profitabilitas merupakan kemampuan perusahaan untuk memperoleh laba selama periode tertentu dengan menggunakan aktiva yang produktif atau modal, baik modal secara keseluruhan maupun modal sendiri (Munawir, 2010; 33).

Profitabilitas dapat diukur dengan menggunakan salah satu rasio Return On Asset (ROA) yang dapat menunjukan seberapa besar laba bersih diperoleh perusahaan bila diukur dari nilai asetnya. Return On Asset (ROA) mempunyai pengaruh yang positif terhadap pertumbuhan laba, karena rasio ini mengukur kemampuan perusahaan dalam menghasilkan laba bersih berdasarkan tingkat aset tertentu. Semakin tinggi profitabilitas perusahaan maka risiko gagal bayar atau default risk akan semakin rendah, sehingga peringkat obligasi yang didapat perusahaan akan semakin tinggi.

\section{Metode Pengukuran Profitabilitas}

Secara matematis Return On Assets (ROA) dapat dihitung dengan rumus sebagai berikut:

$$
\mathrm{ROA}=\frac{\text { Laba Bersih }}{\text { Total Aktiva }} \times 100 \%
$$




\section{Definisi Ukuran Perusahaan}

Ukuran perusahaan dapat diukur dengan total aktiva atau besar harta perusahaan dengan menggunakan logaritma dari total aktiva. Ukuran perusahaan yang diproksikan dengan Ln (log) aktiva diprediksi mempunyai hubungan negatif dengan risiko perusahaan (Jogiyanto Hartono, 2000: 254).

Ukuran perusahaan mempunyai korelasi terhadap tingkat risiko kebangkrutan. Menurut Elton dan Grubber (1995), perusahaan besar yang memiliki risiko yang relatif lebih kecil dibandingkan dengan perusahaan kecil. Semakin besar perusahaan, potensi mendiversifikasikan risikonon-systematic semakin besar, sehingga membuat risiko obligasi perusahaan tersebut menurun. Semakin kecil risiko obligasi perusahaan, maka semakin tinggi pula peringkat obligasi yang diperoleh perusahaan tersebut.

Ukuran perusahaan dapat diukur dengan menggunakan total asset, penjualan dan ekuitas. Perusahaan yang besar memiliki total asset, penjualan dan ekuitas yang besar pula. Sehingga perusahaan yang besar memiliki risiko kebangkrutan atau kegagalan yang lebih rendah bila dibandingkan dengan perusahaan yang kecil.

\section{Struktur Modal}

Struktur modal termasuk kedalam rasio solvabilitas atau leverage merupakan penggunaan aktiva atau dana dimana untuk penggunaan tersebut harus menutup atau membayar beban tetap. Pada prinsipnya rasio ini memberikan gambaran tentang tingkat kecukupan utang perusahaan. Artinya, seberapa besar porsi utang yang ada di perusahaan jika dibandingkan dengan modal atau aset yang ada. Perusahaan yang tidak mempunyai leverage (solvabilitas) berarti menggunakan modal sendiri 100\% (Agus Sartono, 2010:120).

\section{Metode Pengukuran Struktur Modal}

Terdapat beberapa jenis rasio solvabilitas yang sering digunakan perusahaan.antara lain Debt to Asset Ratio (Debt Ratio), Debt to Equity Ratio (DER), Long Term Debt to Equity Ratio, Times interest earned, dan Fixed charge coverage atau lingkup biaya tetap, Kasmir (2013: 155)

Rasio yang digunakan dalam penelitian ini sebagai alat ukur struktur modal adalah Debt to Equity Ratio (DER).

Secara matematis Debt to Equity Ratio (DER) dapat dihitung dengan menggunakan rumus :

$$
\text { DER }=\frac{\text { Total Hutang }}{\text { Total Ekuitas }} \text { 100\% }
$$

\section{Hipotesis Statistik}

\section{Hipotesis Secara Parsial :}

1. Ho $\mathrm{H}_{1}$ : Tidak terdapat pengaruh signifikan antara Profitabilitas terhadap Peringkat Obligasi

$\mathrm{Ha}_{1}$ : Terdapat pengaruh signifikan antara Profitabilitas terhadap Peringkat Obligasi

2. $\mathrm{Ho}_{2}$ : Tidak terdapat pengaruh signifikan antara Ukuran Perusahaan terhadap Peringkat Obligasi

$\mathrm{Ha}_{2}$ : Tidak terdapat pengaruh yang signifikan antara Ukuran Perusahaan terhadap Peringkat Obligasi

3. $\mathrm{Ho}_{3}$ : Tidak terdapat pengaruh yang signifikan antara Struktur Modal terhadap

Peringkat Obligasi

$\mathrm{Ha}_{3}$ : Terdapat Pengaruh yang signifikan antara Struktur Modal terhadap Peringkat Obligasi 


\section{Hipotesis Secara Simultan :}

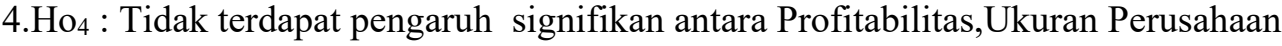

dan Struktur Modal terhadap Peringkat Obligasi

$\mathrm{Ha}_{4}$ : Terdapat pengaruh signifikan antara Profitabilitas Ukuran Perusahaan, dan

Struktur Modal terhadap Peringkat Obligasi.

\section{METODOLOGI PENELITIAN}

\section{Populasi dan Sampel}

Populasi dalam penelitian ini adalah perusahaan sektor keuangan yang tercatat di BEI. Adapun jumlah keseluruhan perusahaan perbankan yang terdaftar di BEI pada tahun 2011-2016 yang menjadi populasi dalam penelitian ini berjumlah 36 perusahaan.Pengambilan Sampel dalam penelitian ini menggunakan metode purposive sampling. Adapun kriteria-kriteria penentuan sampel dalam penelitian ini adalah sebagai berikut:

1. Perusahaan perbankan yang terdaftar di Bursa Efek Indonesia pada periode penelitian, yaitu tahun 2012-2016.

2. Perusahaan perbankan yang memiliki peringkat obligasi yang diterbitkan oleh PT. PEFINDO pada periode penelitian, yaitu 2012-2016.

3. Perusahaan sektor keuangan yang memliki laporan keuangan yang lengkap.

Berdasarkan pada kriteria sampel tersebut, perusahaan perbankan yang dapat dijadikan sampel dalam penelitian ini berjumlah 8 perusahaan.

\section{Jenis Penelitian}

Penelitian ini berbentuk penelitian assosiatif dan menggunakan pendekatan kuantitatif yang bertujuan untuk mengetahui hubungan dua variabel atau lebih (Sugiyono, 2012:114). Penelitian ini bertujuan untuk mengetahui pengaruh variabel independen yaitu Profitabilitas, Ukuran Perusahaan, dan Struktur Modal terhadap variabel dependen yaitu Peringkat Obligasi.

\section{Jenis dan Sumber data}

Jenis data yang digunakan adalah data kuantitatif. Sumber data yang digunakan dalam penelitian ini adalah sumber data sekunder. Data sekunder dalam penelitia ini diperoleh dari situs resmi Bursa Efek Indonesia melalui www.idx.co.id. Dan PT.PEFINDO.

\section{Definisi Operasional variabel dan Skala Pengukuran}

Adapun variabel dalam penelitian ini terdiri dari; Variabel dependen $(\mathrm{Y})$ adalah peringkat obligasi dan Variabel Independen (X) dalam penelitian ini adalah rasio keuangan yang meliputi Profitabilitas $\left(\mathrm{X}_{1}\right)$, Ukuran Perusahaan $\left(\mathrm{X}_{2}\right)$, dan Struktur Modal $\left(\mathrm{X}_{3}\right)$. 
Tabel 2. Daftar Pengukuran Variabel

\begin{tabular}{|c|c|c|}
\hline Variabel Penelitian & Indikator & $\begin{array}{l}\text { Skala } \\
\text { Pengukuran }\end{array}$ \\
\hline $\begin{array}{l}\text { Peringkat Obligasi (Y) } \\
\text { Merupakan skala risiko dari semua } \\
\text { obligasi yang diperdagangkan. Skala } \\
\text { ini menunjukkan seberapa aman } \\
\text { suatu obligasi bagi investor. } \\
\text { Keamanan ini ditunjukkan } \\
\text { darikemampuan perusahaan } \\
\text { dalammembayar bunga dan } \\
\text { pelunasan pokok pinjaman. } \\
\text { (Linandarini, 010). }\end{array}$ & $\begin{array}{l}\text { Dengan memberikan } 7 \text { skala } \\
\text { Peringkat untuk setiap peringkat } \\
\text { yang diterbitkan oleh PEFINDO } \\
\text { skala Peringkat : } \\
\begin{array}{cl}\text { AAA } & =7 \\
\text { AA }= & 6 \\
\text { A }=5 \\
\text { BBB }=4 \\
\text { BB }=3 \\
\text { B }=2 \\
\text { CCC } & =1 \\
\text { D } & =0\end{array}\end{array}$ & Nilai Skala Peringkat \\
\hline $\begin{array}{l}\text { Profitabilitas (X1) } \\
\text { Merupakan kemampuan perusahaan } \\
\text { untuk emperoleh laba selama } \\
\text { periode tertentu dengan } \\
\text { menggunakan aktiva yang produktif } \\
\text { atau modal, baik modal secara } \\
\text { seseluruhan maupun modal sendiri } \\
\text { (Munawir, 2010:33). }\end{array}$ & $\mathrm{ROA}=\frac{\text { Net Income }}{\text { Total Assets }}$ & Rasio \\
\hline $\begin{array}{l}\text { Ukuran Perusahaan/Size } \\
\left(X_{2}\right) \\
\text { Ukuran perusahaan dapat diukur } \\
\text { dengan total aktiva atau besar harta } \\
\text { perusahaan dengan menggunakan } \\
\text { logaritma dari total aktiva.Ukuran } \\
\text { perusahaan yang diproksikan } \\
\text { dengan Ln(log) aktiva diprediksi } \\
\text { mempunyai hubungan negatif } \\
\text { dengan risiko perusahaan } \\
\text { (Jogiyanto Hartono, 2000: 254). }\end{array}$ & Firm Size = Ln TR Rasio & Rasio \\
\hline $\begin{array}{l}\text { Struktur Modal /DER (X3) } \\
\text { Beberapa analis menggunakan } \\
\text { istilah rasio solvabilitas yang berarti } \\
\text { mengukur kemampuan perusahaan } \\
\text { memenuhi kewajiban keuangannya. } \\
\text { Enny (2012:72) }\end{array}$ & $\mathrm{DER}=\frac{\text { Total Liabilities }}{\text { Total Equity }}$ & Rasio \\
\hline
\end{tabular}

\section{Metode Analisis data}

Analisis data yang digunakan dalam penelitian ini menggunakan statistik deskriptif dan analisis logistic regression dengan pengelolaan data melalui software SPSS (Statistical Package for Social Science). Model ini digunakan karena variabel dependen yang digunakan berupa variabel dummy. Teknik analisis ini tidak memerlukan lagi uji normalitas dan uji asumsi klasik pada variabel bebasnya (Ghozali, 2012). 


\section{Model Analisis Regresi Logistik}

Metode analisis ini digunakan untuk menguji pengaruh variabel independen yang berbentuk metrik atau non metrik terhadap variabel dependen yang bersifat kategorial (non metrik). Analisis regresi logistik pada umumnya sama seperti regresi linier, hanya saja variabel dependen yang digunakan berupa variabel non metrik atau dummy. Adapun model analisis regresi logistic dalah sebagai berikut:

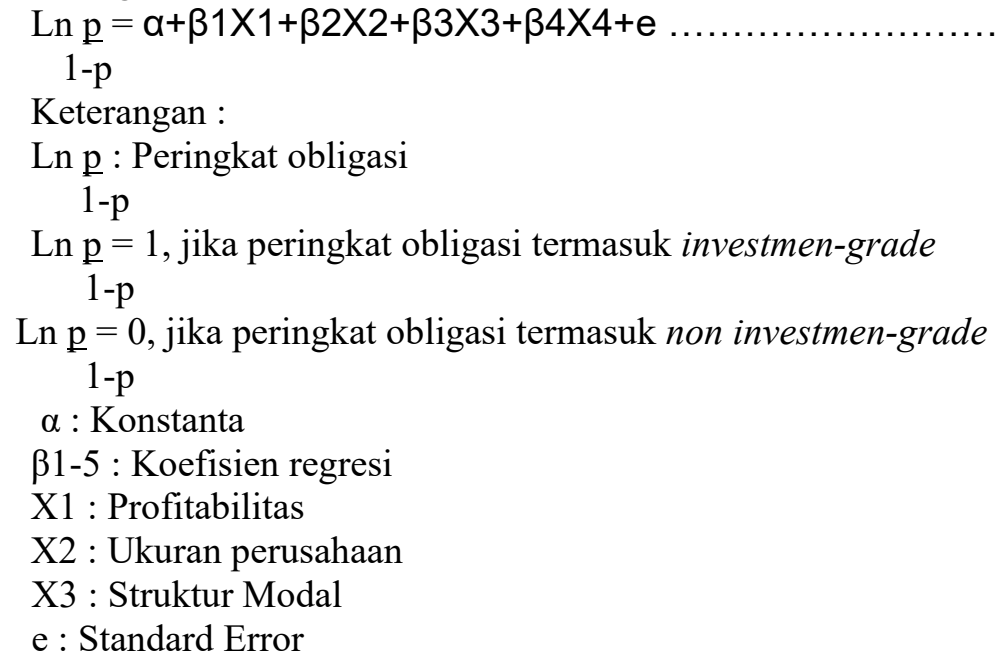

\section{Pengujian Hipotesis}

Pengujian hipotesis ini menggunakan regresi logistik. Tujuan analisis ini adalah untuk mengetahui variabel-variabel independen apa saja yang mampu membedakan antara peringkat obligasi high investment grade dan obligasi low investmen grade. Model ini dgunakan karena variabel dependen yang digunakan berupa variabel dummy (peringkat obligasi kategori high investment $=1$ dan peringkat obligasi kategori low investment $=0$ ). Pengujian hipotesis secara simultan dilihat dari hasil omnibus test of model coefficient. Secara parsial dengan uji wald. Dalam model regresi ini dapat ditaksir dengan menggunakan tahap-tahap sebagai berikut (Ghozali, 2012) :

\section{Menilai Keseluruhan Model (Overal Model Fit)}

Menilai angka -2 log likelihood pada awal (blok number $=0$ ) dan angka -2 log likelihood pada akhir (blok number $=1$ ), jika terjadi penurunan angka -2 log likelihood maka menunjukkan model regresi yang baik. Log likelihood pada regresi logistik mirip dengan pengertian "sum of squared error" pada model regresi, sehingga penurunan log likelihood menunjukkan model regresi yang baik.

\section{Uji Koefisein Determinasi}

Cox and Snell $R$ Square dan Nagelkerke R Square Menurut Imam Ghozali (2011: 341) Cox and Snell $R$ Square merupakan ukuran yang mencoba meniru ukuran R Square pada multiple regression yang didasarkan pada teknik estimasi likelihood dengan nilai maksimum kurang dari 1 (satu) sehingga sulit diinterpretasikan. Nagelkerke $R$ Square merupakan modifikasi dari koefisien Cox and Snell $R$ Square untuk memastikan bahwa nilainya bervariasi dari 0 (nol) sampai 1 (satu). Hal ini dilakukan dengan cara membagi nilai Cox and Snell's $R$ Square dengan nilai maksimumnya. Nilai Nagelkerke $R$ Square dapat diinterprestasikan seperti nilai $R$ Square pada multiple regression. Hasilnya akan menunjukkan persentase variabilitas variabel terikat yang dapat dijelaskan oleh variabilitas variabel bebasnya.

\section{Menguji Kebaikan Model (goodness of fit test)}

Menguji hipotesis nol bahwa data empiris cocok atau sesuai dengan model (tidak ada perbedaan antara model dengan data sehingga model dapat dikatakan fit). Hipotesisnya adalah : 
Ho: Tidak ada perbedaan signifikan antara model dengan nila observasinya

Ha: Ada perbedaan signifikan antara model dengan nilai observasinya Dasar pengambilan keputusan nilai goodness of fit test yang diukur dengan nilai chi square pada bagian bawah uji Hosmer dan Lemeshow:

Jika probabilitas $>0,05 \mathrm{H} 0$ diterima

Jika probabilitas $<0,05 \mathrm{H} 0$ ditolak

\section{Uji Signifikan Simultan (Uji F)}

Pada regresi logistik menguji signifikansi simultan menggunakan nilai Chi-square dari selisih nilai antara -2 log likelihood sebelum variabel independen masuk model dan -2 log likelihood setelah variabel independen masuk pada tingkat kepercayaan 95\% atau $\alpha=5 \%$.

\section{Uji Koefisien Regresi secara Parsial (Uji T)}

Uji Wald setara dengan uji t. Uji ini dilakukan untuk mengetahui pengaruh variabel independen terhadap variabel bebas secara parsial dengan menganggap variabel bebasnya konstan. Hipotesis yang digunakan dalam uji adalah :

$\mathrm{H} 0: \beta \mathrm{i}=0$

$\mathrm{H} 1: \beta \mathrm{i} \neq 0$

Hipotesis nol menunjukkan tidak ada pengaruh variabel independen terhadap variabel dependen ketika variabel Xi konstan. Jika nilai Sig $<0.05$ maka H0 ditolak dan H1 diterima atau dapat dikatakan variabel independen berpengaruh terhadap variabel dependen.

\section{PEMBAHASAN}

\section{Uji Hosmer and Lemeshow Test}

Uji Hosmer and Lemeshow Test gunanya untuk menguji Kelayakan model regresi Logistik ordinal,hasil pengujian dapat dilihat dari Tabel 4.2 Hosmer and Lemeshow Test berikut ini:

Tabel 3

Hasil Uji Hosmer and Lemeshow Test

\begin{tabular}{|l|r|r|rr|}
\hline Step & Chi-square & \multicolumn{1}{|c|}{ Df } & \multicolumn{2}{|c|}{ Sig. } \\
\hline 1 & 8.653 & 8 & & .372 \\
\hline
\end{tabular}

Sumber : data sekunder diolah, (2018)

Model regresi logistik pada penelitian ini menunjukkan nilai statistik Hosmer and Lemeshow Test sebesar 8,653 dengan probabilitas signifikan 0,372. Nilai signifikan lebih besar dari $5 \%(0,372>0,05)$, ini menunjukkan bahwa model dalam penelitian ini dapat diterima karena cocok dengan data observasinya. Keseluruhan model dinilai dengan membandingkan nilai antara -2 Log likehood pada awal (block number $=0$ ) dengan nilai -2 Log likehood pada akhir (block number $=1$ ). Nilai -2 Log likehood seperti yang disajikan pada tabel berikut.

Tabel 4

Menilai keseluruhan Model (Iteration History ${ }^{a, b, c}$ )

\begin{tabular}{|rr|r|rr|}
\hline Iteration & & -2 Log & \multicolumn{2}{|c|}{ Coefficients } \\
\cline { 4 - 5 } & & likelihood & Constant \\
\hline \multirow{3}{*}{ Step 0 } & 1 & 28.176 & & 1.375 \\
& 2 & 27.741 & & 1.658 \\
& 3 & 27.738 & & 1.686 \\
& 4 & 27.738 & & 1.686 \\
\hline
\end{tabular}

Sumber : data sekunder diolah, (2018)

Dari nilai -2 Log Likelihood pada akhir mengalami penurunan dibandingkan dengan nilai -2 Log Likelihood awal dan nilai signifikan Sehingga dapat disimpulkan bahwa model fit. Dan model lebih baik dengan memasukan variabel independen disbanding hanya dengan intercept saja. 
Tabel 5

Menilai keseluruhan Model (Iteration History ${ }^{a, b, c, d}$ )

\begin{tabular}{|c|c|c|c|c|c|}
\hline \multirow[t]{2}{*}{ Iteration } & \multirow{2}{*}{$\begin{array}{c}-2 \text { Log } \\
\text { likelihood }\end{array}$} & \multicolumn{4}{|c|}{ Coefficients } \\
\hline & & Constant & ROA & SIZE & DER \\
\hline \multirow{6}{*}{ Step 1} & 25.993 & -.667 & .033 & .231 & -.231 \\
\hline & 23.938 & -2.169 & .218 & .450 & -.470 \\
\hline & 23.098 & -3.328 & .695 & .607 & -.675 \\
\hline & 22.951 & -3.811 & 1.010 & .683 & -.787 \\
\hline & 22.949 & -3.854 & 1.056 & .693 & -.804 \\
\hline & 22.949 & -3.854 & 1.057 & .693 & -.804 \\
\hline
\end{tabular}

Sumber : data sekunder diolah, (2018)

\section{Uji Regresi Logistik}

Analisis logistic digunakan untuk melihat pengaruh sejumlah variabel independen $\mathrm{X} 1$ (ROA), X2 (SIZE), dan X3(DER) terhadap variabel dependen Peringkat Obligasi (Y). Model regresi logistik dapat dibentuk dengan melihat pada nilai estimasi parameter dalam Variables in The Equation. Model regresi yang terbentuk berdasarkan nilai estimasi parameter dalam Variables in The Equation ditampilkan pada Tabel 6 berikut ini.

Tabel 6 Analisis Regresi Logistik

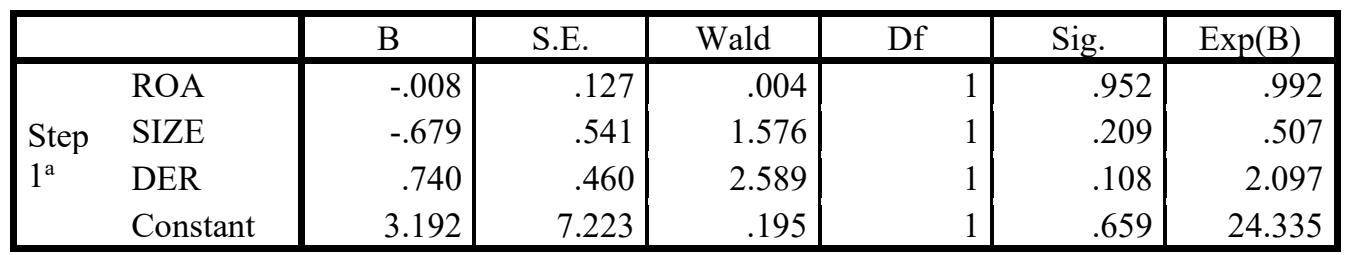

Sumber : data sekunder diolah, (2018)

Model regresi yang terbentuk berdasarkan nilai estimasi parameter dalam Variables in The Equiation adalah sebagai berikut.

$\operatorname{Ln} \underline{\mathrm{P}}=3,192+-0,008 \mathrm{ROA}+-0,679 \mathrm{SIZE}+0,740 \mathrm{DER}$

Nilai konstanta yang diperoleh adalah sebesar 3,192, hal ini menunjukkan bahwa jika variabel independen yaitu profitabilitas, ukuran perusahaan, dan struktur modal bernilai nol, maka probabilitas peringkat obligasi sebesar nilai odds ratio $\operatorname{Exp}(3,192)=24.34$. Berdasarkan hasil uji regresi logistic yang disajikan dalam bentuk persamaan regresi dapat diinterpretasikan sebagai berikut:

1. Nilai koefisien regresi variabel profitabilitas perusahaan yang diukur dengan Current On Asset (ROA) adalah sebesar -0,008 dengan nilai odds ratio sebesar $\operatorname{Exp}(0,008)=1,008$. Hal ini menunjukkan kecendrungan tingkat profitabilitas mempunyai hubungan negatif dalam mempengaruhi peringkat obligasi. Setiap kenaikan profitabilitas sebesar satu point,berpotensi memprediksi peringkat obligasi yang investment grade 1.008 kali.

2. Nilai koefisien regresi variabel ukuran perusahaan yang diukur dengan Ln (Total Aset) adalah sebesar $-0,679$ dengan nilai odds ratio sebesar $\operatorname{Exp}(0,679)=1.972$. Hal ini menunjukkan bahwa ukuran perusahaan mempunyai hubungan negatif dalam mempengaruhi peringkat obligasi. Setiap kenaikan ukuran perusahaan sebesar satu point berpotensi memprediksi peringkat obligasi yang investment grade sebesar 1,972 kali.

3. Nilai koefisien regresi variabel struktur modal perusahaan yang diukur dengan rasio Debt to Equity Ratio (DER) adalah sebesar 0,740 dengan nilai odds ratio sebesar $\operatorname{Exp}(0,740)=2,096$. Hal ini menunjukkan bahwa struktur modal mempunyai hubungan 
positif,setiap peningkatan satu point berpotensi memprediksi peringkat obligasi yang investmen grade sebesar 2,096 kali.

\section{Pengujian Hipotesis}

Pengujian hipotesis dilakukan dengan cara membandingkan tingkat signifikansi (sig.) dengan $\alpha$ sebesar 5\%. Berdasarkan Tabel 4.5. dapat diinterprestasikan hasil sebagai berikut.

1. Variabel profitabilitas dengan nilai signifikansi $0,952>0,05$ hal berarti bahwa H1 diterima, dengan demikian menunjukan bahwa profitabilitas berpengaruh signifikan terhadap peringkat obligasi.

2. Variabel ukuran perusahaan dengan nilai signifikansi $0,209>0,05$ hal ini mengandung arti bahwa $\mathrm{H} 2$ diterima, dengan demikian menunjukan bahwa ukuran perusahaan berpengaruh signifikan terhadap peringkat obligasi.

3. Variabel DER dengan nilai signifikansi 0,108 $>0,05$ hal ini mengandung arti bahwa H3 diterima, dengan demikian menunjukan bahwa DER berpengaruh positif signifikan terhadap peringkat obligasi.

Tabel 7. Koefisien Determinasi

Model Summary

\begin{tabular}{|l|r|r|r|}
\hline Step & $\begin{array}{c}-2 \text { Log } \\
\text { likelihood }\end{array}$ & $\begin{array}{c}\text { Cox \& Snell R } \\
\text { Square }\end{array}$ & $\begin{array}{c}\text { Nagelkerke R } \\
\text { Square }\end{array}$ \\
\hline 1 & $22.949^{\mathrm{a}}$ & .139 & .240 \\
\hline
\end{tabular}

Sumber : data sekunder diolah, (2018)

Kuatnya hubungan variabel independen terhadap variabel dependen dapat dilihat dari nilai Nagelkerke R Square. Tabel 7 menunjukkan nilai Nagelkerke R Square sebesar 0,24. Nilai tersebut berarti bahwa variasi dari ROA, SIZE, dan DER (variabel independen) mampu menjelaskan variasi dari peringkat obligasi (variabel dependen) sebesar $24 \%$, sedangkan sisanya sebesar $76 \%$ dijelaskan oleh variasi variabel lain yang tidak dimasukkan dalam model persamaan regresi.

\section{Pembahasan}

Perbandingan Hasil Penelitian dengan Teori

Pengaruh Profitabilitas (X1) terhadap Peringkat Obligasi (Y)

Hipotesis pertama, berdasarkan hasil pengujian hipotesis, dapat diketahui bahwa variabel profitabilitas memiliki nilai koefisien regresi odds ratio sebesar 1,008 dengan nilai signifikansi $0,952>\alpha=0,05$, hasil tersebut menunjukkan bahwa H1 diterima. Hasil penelitian ini tidak konsisten dengan teori yang menyatakan apabila profitabilitas meningkat maka peringkat obligasi juga akan berpotensi meningkat.

Pengaruh Ukuran Perusahaan (X2) terhadap Peringkat Obligasi (Y) pada sektor keuangan.

Hipotesis kedua, dalam penelitian ini adalah ukuran perusahaan berpengaruh negative dan signifikan terhadap peringkat obligasi. Berdasarkan hasil pengujian hipotesis, dapat diketahui bahwa variabel ukuran perusahaan memiliki nilai koefisien regresi sebesar $-0,679$ dengan odds ratio 1.972 dengan nilai signifikansi $0,209<\alpha=0,05$ yang memiliki arti bahwa H1 diterima artinya ukuran perusahaan berpengaruh secara negatif dan signifikan terhadap peringkat obligasi.Hasil penelitian menunjukkan tidak konsisten dengan teori bahwa semakin besar ukuran perusahaan, maka semakin rendah peringkat obligasi.

Pengaruh Struktur Modal (X3) terhadap Peringkat Obligasi (Y) pada sektor keuangan.

Hipotesis ketiga, dalam penelitian ini adalah struktur modal berpengaruh positif signifikan terhadap peringkat obligasi. Berdasarkan hasil pengujian hipotesis, dapat diketahui bahwa variabel DER memiliki nilai koefisien regresi dengan odds ratio sebesar 2.096 dengan nilai signifikansi $0,108>\alpha=0,05$ yang memiliki arti bahwa $\mathrm{H} 1$ diterima sesuai dengan tori.

Pengaruh Profitabilitas(X1), Ukuran Perusahaan(X2) dan Struktur Modal(X3) terhadap peringkat obligasi $(\mathrm{Y})$ pada sektor keuangan. 
Hasil menunjukan nilai signifikan yang diperoleh adalah $0,000<0.05$. Hal ini secara simultan variabel Profitabilitas, Ukuran Perusahaan dan Struktur Modal berpengaruh terhadap peringkat obligasi pada sektor keuangan.

\section{PENUTUP}

\section{Kesimpulan}

Dari hasil uji statistik dan analisis data maka hasil penelitian dapat disimpulkan sebagai berikut :

1. Profitabilitas berpengaruh signifikan terhadap peringkat obligasi. Profitabilitas mempunyai hubungan negatif dalam mempengaruhi peringkat obligasi.

2. Ukuran perusahaan berpengaruh negatif dan signifikan terhadap peringkat obligasi.

3. struktur modal berpengaruh positif signifikan terhadap peringkat obligasi.

4. Profitabilitas, ukuran perusahaan dan struktur modal secara simultan berpengaruh

\section{Saran} signifikan terhadap variabel peringkat obligasi.

Keterbatasan dalam melakukan penelitian maka peneliti menyarankan bagi peneliti selanjutnya sebagai berikut:

1. Penelitian yang akan datang sebaiknya meneliti pengaruh peringkat obligasi dari variabel lainnya yang memungkinkan untuk mempengaruhi peringkat obligasi

2. Penelitian yang akan datang sebaiknya meneliti pengaruh peringkat obligasi bukan saja dari factor keungan tetapi juga non keuangan.

\section{DAFTAR PUSTAKA}

Agus Sartono. 2010. Manajemen Keuangan Teori dan Aplikasi. Edisi 4. Yogjakarta: BPFE.

Amalia, Ninik. 2013. Pemeringkatan Obligasi PT. Pefindo Berdasarkan Informasi Keuangan. Accounting Analysis Journal, 2 (2), h:140-147.

Brigham F.Eugene dan Huston, Joel. 2013. Dasar-dasar Manajemen Keuangan Essentials of Financial Manajement. Jakarta : Salemba Empat.

Dr. J.P Sitanggang. 2014. Manajemen Keuangan Perusahaan. Edisi Kedua. Mitra Wacana Media. Fahmi, Irham. 2013. Analisis Laporan Keuangan. Cetakan Ke-3. Bandung : Alfabeta.

Fauziah, Y. 2014. Pengaruh Likuiditas, Leverage Dan Umur Obligasi Terhadap Prediksi Peringkat Obligasi. Jurnal Akuntansi Universitas Negeri Padang, 2 (1), h:1-24.

Ghozali, I. 2013. "Aplikasi Analisis Multivariate dengan Program IBM SPSS”, ed 21, Cetakan VII. UNDIP. Semarang.

Hanafi, Mamduh M. Dan Halim, Abdul. 2012. Analisis Laporan Keuangan. Yogyakarta : UPP STIM YKPN.

Kasmir. 2013. Analisis Laporan Keuangan, Cetakan Ke-6. Jakarta : Raja Grafindo Persada.

Linandarini, E. (2010). Kemampuan Rasio Keuangan Dalam Memprediksi Peringkat Obligasi Perusahaan Indonesia.

Maharti, Enny Dwi. 2011. Analisis Faktor-faktor yang Mempengaruhi Peringkat Obligasi. Skripsi. Semarang: Undip.

Munawir, S. 2010. Analisis Laporan Keuangan. Edisi 4. Yogyakarta : Liberty.

Prof. Dr. Ahmad Rodoni. Dr. Herni Ali, HT, SE, MM. 2014. Manajemen Keuangan Modern. Penerbit Mitra Wacana Media, Jakarta.

Suad Husnan dan Enny Pudjiastuti. 2011. Dasar-Dasar Manajemen Keuangan. Yogyakarta: Penerbit UPP STIM YKPN.

Sugiyono. 2013. "Metode Penelitian Bisnis (Pendekatan Kuantitatif, Kualitatif, dan R \& D)". Bandung: Alfabeta.

Tandelilin, Eduardus. 2010. Analisis Investasi dan Manajemen Portofolio. Yogyakarta: BPFE. 
Yuliana, Rika. Dkk. 2011. Analisis Faktor-faktor yang Mempengaruhi Peringkat Obligasi pada Perusahaan Keuangan yang Terdafar di Bursa Efek Indonesia. SNA XIV.

Sumber lainnya :

Keputusan BAPEPAM dan Lembaga Keuangan Kep-151/BL/2009.

www.idx.co.id

www.pefindo.com 